\title{
Cashless Economic Policy in Nigeria: A Performance Appraisal of The Banking Industry.
}

\author{
Ordu Monday Matthew ${ }^{1}$, Anyanwaokoro, Mike ${ }^{2}$ \\ ${ }^{I}$ Department of Banking and Finance, Faculty of Management Sciences, Enugu State University of Science and \\ Technology (ESUT), Enugu, Enugu State. Nigeria
}

\begin{abstract}
It is a known fact that the financial sector reform is an essential ingredient in the economic growth and developmental process of every nation. This is clearly underscored in the literature linking the growth in financial sector with national economic growth. Hence the financial sector is regarded as the pivot of every economy. In recognition of this fact, managers of the Nigerian economy have targeted the banking sector as a channel for implementing economic policy reforms and policy shift to enhance its developmental process. Consequently, in January 2012, such economic reform in the Nigerian financial sector was exercised with the formal introduction of the cashless economic policy. The interest which the policy generated is hardly surprising considering the enormous implications its application will have on the lives of the ordinary Nigerians and the business environment. What are the benefits and challenges of this policy vis-à-vis the cash based policy and how has the banking industry performed under the policy? Against this backdrop, this paper appraises the performance of Nigerian banking industry given the adoption of the cashless economic policy in Nigeria vis-àvis the cash based period with a view to x-raying the possible challenges and benefits which it poses to the Nigerian economy. Data utilized were sourced from the published annual reports of sampled banks and analytically, the study employs thet-test analytical technique to test whether there is a significant difference in the performance of bank in Nigeria before and after the adoption of the cashless policy.. The study found out that though the cashless policy is not a policy designed to enhance bank profitability but it has a lot of benefits associated with it which include; increased convenience; reduced risk of cash related crimes; reduced cash handling cost, reduced revenue leakages among others. However, the policy is beset with challenges which include; infrastructural deficits, erratic power supply, prevalence of e-fraud, high illiteracy level among others. It is recommended that the Federal Government of Nigeria and the Central Bank of Nigeria should synchronize their efforts in ensuring cyber-safety which is a major threat to the e-payment system in order to fully harness the smiles of cashless policy in Nigeria. Therefore, Nigerian banks should utilize the benefits of the cashless policy and engage in efficient financial intermediation for enhanced bank profitability. Further, appropriate infrastructures such as improvement on the power sector should be made to enhance the smooth operation of the policy.
\end{abstract}

Keywords: Cashless policy, e-payment, Payment channels, ROA

\section{Introduction}

One of the most compelling propositions put forward by the Central Bank of Nigeria (CBN) in the defense of its new policy on cash-based transactions (cash-less policy) is that:

An efficient and modern payment system is positively correlated with economic development, and is a key enabler for economic growth

Since Nigerian independence in 1960, there have been different governments, constitutional reforms, changes in economic and financial policies mainly aimed at stabilizing the economy, enhancing social welfare and enhancing economic growth and development. The Central Bank of Nigeria (CBN) has in recent times engaged in series of reformations aimed at both making the Nigerian financial system formidable and enhancing the overall economic performance of Nigeria so as to place it on the right path in line with global trends. Various policy initiatives that were put in place include the capitalization (minimum requirement of N25billion) agenda (Ajayi, 2006); the aborted move at redenomination of the Naira and the Islamic banking (non-interest banking). (Babalola, 2008). Some of these policy measures came with tremendous success despite their initial criticism. For instance the N25billion capitalization transformed the banking landscape from a system formerly dominated by "fringe banks" to one made up of largely "mega banks" (Adeyemi, 2006). The product of the exercise was to "ensure a diversified, strong and reliable banking industry where there is safety of depositors' money, and reposition the banks to play active developmental roles in the Nigerian economy" (Adegbaju and Olokoyo, 2008).

Before the emergence of modern banking system, banking operations were manually done. The manual system which involved posting of transactions from one ledger to another without the aid of computer systems accounted for inefficiency in settlement of transactions. Computations done manually led to miscalculation due 
to human errors, and resulted in extension of closing hours when account were not balanced on time. Furthermore, a cash based economy also imposes some costs on the banking system, individuals, and the government. The higher the velocity of cash usage, the higher the processing cost borne by those in the value chain. There is, for instance, the cost of printing new notes to replace the ones that are torn or worn out due to frequent handling (Osazevbaru and Yomere, 2015). The introduction of cashless system is therefore meant to ameliorate the sluggish nature of banking transactions.

But the recent evolution of information and communication technology (ICT) has influenced every facet of life, transforming subsistence societies into modernized societies. The introduction of this technology into the banking industry has re-defined banking operations and has increasingly fuelled the use of electronicbased payment instruments globally. In advanced economies like the United States, the use of cash for purchasing consumption goods has declined from 39\% in 1974 to $16 \%$ in 2000. Although there may have been multi-year upward and downward trends in cash use during this period, cash use has fallen absolutely since 1992. During this period, cards clearly replaced cash. Although cash use is falling, it will not go to zero (Humphrey, 2004). Most developing countries like South Africa, Uganda etc. were on the transition from pure cash economy to cashless one for developmental purposes. To key into this global trend, the Central Bank of Nigeria $(\mathrm{CBN})$ in collaboration with the Bankers Committee recently introduced the cashless policy which according to the apex bank is aimed at:

1) Driving development and modernization of Nigeria's payment system in line with Nigeria's vision 2020 goal of being amongst the top 20 economies in the world by the year 2020. It is a known fact that an efficient and modern payment system is a key enabler for economic growth and must positively correlate with economic development.

2) To reduce the cost of banking services (including cost of credit) and drive financial inclusion by providing more efficient transaction options and greater reach and to improve the effectiveness of monetary policy in managing inflation and driving economic growth.

3) To improve the effectiveness of monetary policy in managing inflation and driving economic growth. And also curbing some of the negative consequences associated with the high usage of physical cash in the economy including: high cost of cash: high risk of using cash; high subsidy, informal economy and inefficiency and corruption (CBN, Website, 2011).

On January 1, 2012, Phase 1 which is the pilot scheme of mobile money, one of the financial services introduced by the Central Bank of Nigeria, via a CBN circular Ref. No. COD/DIR/GEN/CIT/05/031 dated 20th April, 2011, to achieve a cashless economy took off in Lagos state, the country's economic hub with the aim of achieving an environment where a higher and increasing proportion of transactions are carried out through cheques and electronic payments in line with the global trend (Obodo,2012). The statistical evidence provided by Central Bank of Nigeria in 2012 revealed that, cash-related transactions accounted for 99\% of customers' activities in Nigerian banks as at December, 2011. It estimated the total cash transaction volume through the conventional five payment channels to be $215,015,005$ transactions in December 2011. Of this figure, ATM withdrawal accounted for $50.9 \%$, over-the-counter (OTC) withdrawal, $33.72 \%$ and cheques $13.56 \%$, Point of sales (POS) and web channels accounted for $0.49 \%$ and $1.26 \%$ respectively. Obviously, the combination of ATM and OTC withdrawals amounting to $84.96 \%$ justifies the claim of the CBN that the Nigerian economy is heavily cash-based and the imperative for cashless economy. Furthermore, a cash-based economy also imposes some costs on the banking system, individuals, and the government. The higher the velocity of cash usage, the higher the processing cost borne by those in the value chain. There is, for instance, the cost of printing new notes to replace the ones that are torn or worn out due to frequent handling. Central Bank of Nigeria (2011) states that this cost is high and also on the increase hence the attempted redenomination of the currency. It puts the direct cost of cash to the Nigerian financial system as at 2009 at a colossal amount of N114.5 billion. (The figure is based on actual data from the CBN and 17 banks in the FSI). It excludes bank cash infrastructure cost and employee costs attributable to cash logistics. This amount is broken down into: cash in transit cost N27.3 billion (24\%), cash processing cost N89.1billion (67\%), and vault management cost N18.1 billion (9\%). The estimated cost of cash by the end of 2012 was put at N192billion. Clearly, this evidence provides a platform for migration to cashless economy.

In view of the above, the Central Bank of Nigeria (CBN) introduced the new policy on cash-based transactions which stipulates a cash handling charge on daily cash withdrawals that exceed N500,000 for individuals and N3,000,000 for Corporate bodies. This policy on cash-based transactions (withdrawals) in banks, is aimed at reducing (not eliminating) the amount of physical cash (coins and notes) circulating in the economy, and encouraging more electronic-based transactions (payments for goods, services, transfers, etc.). The following aspects of the policy were applied from January 1st 2012 during the pilot scheme in Lagos State (tagged Cashless Lagos): 
$>$ Only CIT licensed companies were allowed to provide cash pick-up services. Banks ceased cash in transit lodgment services rendered to merchant-customers in Lagos State from December 31st 2011. Sanction was placed on banks that continue to offer cash in transit lodgment services to merchants.

$>$ Third party cheques above N150, 000 shall not be eligible for encashment over the counter. Value for such cheques shall be received through the clearing house.

While phase 2 of the policy took effect in Rivers, Anambra, Abia, Kano, Ogun and the Federal Capital Territory (FCT) on the 1st of October, 2013, Phase 3 and final phase of the policy was fully implemented nationwide on July 1st, 2014. The charges on withdrawals for both individual and corporate account holders took effect in the 30 States from July 1, 2015. The waiver, the CBN explained, would allow ample time for the deployment of adequate infrastructure needed to support the policy, as well as additional sensitization of various stakeholders on the merits of the policy. In effect, $3 \%$ charge for individual on daily cumulative or single cash withdrawals in excess of N500,000, and 5\% charge for corporate bodies on daily cumulative or single cash withdrawals in excess of N3million was suspended in the 30 states and was effective from July 1, 2015. However, while the policy applies to all accounts, the exceptions include Government revenue generation account, Primary Mortgage Institutions, Microfinance Banks and Embassies. Thus given that transaction charges are one of the major income earner for banks, this study therefore comparatively appraises bank income under the cash-based economy with bank income under the cashless economic policy.

Alagh and Ene (2014) noted that the volume and value of electronic card (e-card) transactions has increased significantly from N195,525,568 and N1,072.9 billion in 2010 to N355,252,401 and N1,671.4 billion, in 2011 reflecting an increase of 81.5 and 55.8 per cent, respectively. The increase was attributed to enhanced public confidence in electronic card payments. In addition, data on various e-payment channels from Alagh and Ene (2014) indicated that ATMs remained the most patronized accounting for 97.8 per cent, followed by web payments, 1.0 per cent, Point-of-Sale (POS) terminals, and mobile payments, 0.6 per cent each. Similarly, in value terms, ATMs accounted for 93.4 per cent, web 3.5 per cent, POS 1.9 per cent and mobile payments, 1.2 per cent. The number of ATMs stood at 9,640, while the volume and value of transactions amounted to 347,569,999 and N1, 561.75 billion, at end-December 2011, respectively. These figures reflected increases of 86.7 and 63.7 per cent respectively over the volume and value of 186,153,142 and N954.04 billion, at endDecember 2010 (Alagh and Ene, 2014). The volume and value of mobile payments increased by 215.6 and 185.8 per cent from 1,156,553 and N6.7 billion to 3,649,374 and N19.0 billion, respectively, at end-December 2011. However, irrespective of these notable increases in volumes and values utilizing the e-payment channels, the CBN money and credit statistics (financial intermediation statistics including reduction in currency outside the banks, increase in demand deposits as well as bank credit) fails to record significant gains. It is expected that the increase in the usage of e-payment solutions of ATM, POS, mobile money etc will greatly reduce the currency outside banks but available monthly statistics shows that currency outside the bank recorded increasing rates in growth in 2014 of $0.12 \%, 6.41 \%, 2.32 \%, 3.86 \%$ and $11 \%$ in the months of March, June, August, October and November respectively. Year 2014 also reports negative growth in rates in demand deposits of $2.36 \%,-2 \%,-4.16 \%,-0.86 \%,-2.18 \%$ and $-10 \%$ for months of April, May, July, September through November respectively. Given these, banks credit to the private sector failed to increase above $1.7 \%$ throughout 2014 while specifically recording growth rates of less than $1 \%$ of $-0.24 \%, 0.85 \%$ and $0.10 \%$ in April, July and November respectively. Thus, these imply that the cashless policy is not yielding the desired result in financial intermediation and has implications for bank profitability. Hence, this study examines and analyses bank profitability under the cashless policy.

The study aims at appraising the performance of Nigerian banking industry given the adoption of the cashless economic policy in Nigeria vis-à-vis the cash based period with a view to X-raying the possible challenges and benefits which it poses to the Nigerian economy. The rest of the research paper is organized into four sections as follows: Section 2 reviews existing literature in the area of study, section3 enlists the methodology applied for analysis, section 4 discusses the empirical results/ findings while section 5concludes after the summary.

\subsection{Conceptual Framework}

\section{Review of Related Literature}

Cashless economy is a global phenomenon. Contrary to its literary meaning, it does not mean to an outright absence of cash transactions in the economic setting but the reduction of the amount of cash-based transactions to the barest minimum. Cashless economy is an economy where transaction can be done without necessarily carrying physical cash as a means of exchange of transaction but rather with the use of credit or debit card payment for goods and services. It is an economic setting in which goods and services are bought and paid for through electronic media (Okoye and Ezejiofor, 2013). Cashless economy does not mean a total elimination of cash as money will continue to be a means of exchange for goods and services in the foreseeable 
future. It is a financial environment that minimizes the use of physical cash by providing alternative channels for making payments (Alilonu, 2012). Cashless economy is an environment in which money is spent without being physically carried from one person or place to the other. Similarly, a cashless society is a culture where no one uses cash, all purchases being made are by credit cards, charge cards, cheques, or direct transfers from one account to another through mobile banking. The cashless society here refers to the widespread application of computer technology in the financial system.

The cashless economy policy of the $\mathrm{CBN}$ is designed to provide mobile payment services, breakdown the traditional barriers hindering financial inclusion of millions of Nigerians and bring low cost, secure and convenient financial services to urban, semi-urban and rural areas across the country. This has however become an albatross to some elites, the poor, the uneducated and traders (Eromosele and Obinna, 2012). Cashless economy according to Nweke (2012) is an economy where the physical cash circulating in the economy is minimized while other forms of payment, especially electronic based payments, are utilized. In other words, a cashless economy is a combination of the cash-based payment system and electronic payment systems, with the latter exceeding the former in terms of utilization. A cashless economy represents the pure state of non-cash payment systems where no more sturdy coins and notes are printed for circulation by the Central Bank. As Costa and Grauwe (2001) define it, a cashless society is a regime in which currency issued by the central bank has ceased to exist. All the money is private money issued by banks in the form of deposits, or some fancier emoney issued by institutions that are not necessarily banks. Obi (2012) defines cashless society as one where no one uses cash, all purchases being made by credit cards, charge cards, cheques and direct transfers from one account to another. In other words, it refers to the widespread application of computer technology in the financial system. According to him, in the western world today, almost $97 \%$ of transactions are done without physical cash being exchanged and this has greatly reduced cost, corruption and money laundering. In Nigeria today, it is the opposite - with majority of transactions done with cash. In a cashless economy, how much cash in your wallet is practically irrelevant. You can pay for your purchases by any one of a plethora of credit cards or bank transfer (Roth, 2010). Some aspects of the functioning of the cashless economy are enhanced by efinance, e-money, e-brokering and e-exchange. These all refer to how transactions and payments are affected in a cashless economy (Ashike, 2011).

Similarly, Woodford (2003) defined the cashless economy as "one in which there are assumed to be no transactions frictions that can be reduced through the use of money balances, and that accordingly provide a reason for holding such balances even when they earn rate of return." Cashless banking is that banking system which aims at reducing, but not eliminating, the volume of physical cash circulating in the economy while encouraging more electronic based transactions. In other words, it is a combination of e-banking and cash-based system. It is essentially a mobile payment system which allows users to make payment through GSM phones with or without internet facilities (Odior and Banuso, 2012; Akhalumeh and Ohiokha, 2012; Osazevbaru and Yomere, 2015). A cashless economy, according to Adewale (2012) simply illustrates a gradual or a radical movement of the entire payment system of an economy from the use of physical cash to a systemic adoption of other non-physical cash mode of payments in settlements of all types of transactions, including all commercial, homes, personal, local and international trade both in public and private life within the economy. Cashless economy simply implies that all means of payments are carried out without the use of physical cash. Payments will range from online transactions, mobile banking, debit and credit cards, cheques, and wire transfer etc. In other words, financial transactions can be carried out anywhere via the internet with the use of computers and mobile devices. It is the latest electronic banking innovation and a revolution changing the lives of millions across the globe. Hence, a cashless economy is a situation where there is little or very low cash flow in a given society, thus every other purchases and transactions will be made via electronic channels. Humphrey (2004) observed that developed countries of the world, to a large extent, are moving away from paper payment instruments toward electronic ones, especially payment cards. Marco and Bandiera (2004) argue that increased usage of cashless banking instruments strengthens monetary policy effectiveness and that the current level of emoney usage does not pose a threat to the stability of the financial system. However, it does conclude that central banks can lose control over monetary policy if the government does not run a responsible fiscal policy.

In 2011, it was estimated that $99 \%$ of over 215 million customer transactions in Nigerian banks were through ATM and over-the-counter, and this was valued at about N2.1 trillion. It is estimated that an average Nigerian transacts about N65 in cash out of N100 income earned (Princewell and Anuforo, 2013). The operation of the cash based system has been at a significant cost to the Nigerian economy. The estimate shows that cash distribution cost accounts for $60 \%$ overheads in the banking industry while cash management operations require up to $80 \%$ of the industry's infrastructure base and staff strength (CBN, 2012). Furthermore, the direct cost of transporting, processing and storing (vault) huge volume of cash borne by the financial system was valued atN114.5 billion in 2009 and it was estimated to rise to N192 billion by the end of 2012. Again, heavy cash users (i.e. those with transaction value above N150,000) account for only $10 \%$ of transaction volume but $71 \%$ of the transaction value. It appears therefore, that implicit cash holding costs for the minority class of cash users 
are being subsidized by the majority (Nweke,2012).In response to this trend, the Central Bank of Nigeria by its legal mandate initiated the policy shift from cash-based system to cash-less one. In 2005, the CBN initiated the National Payment Systems (NPS) specifically to achieve the objectives of promoting efficiency and effectiveness of payment system, promoting safe and sound banking practices and protection against systemic risks. It also set the objective of migrating to cash-less mode of payment, such as electronic debit/credit instruments, credit/debit cards, ATM - sharing Electronic Fund Transfer at Point of Sales and Real Time Gross Settlement System (RTGS). Other objectives of NPS include; to ensure payment system audit transparency and full transaction reporting and to achieve acceptance and confidence through information dissemination, customer convenience and total quality delivery (Princewell and Anuforo, 2013). Eventually, the NPS initiative metamorphosed into the cashless policy on April 20, 2011.

According to CBN (2011), the cashless policy aims at reducing the amount of physical cash in circulation and to encourage more electronic based transactions. The policy came into effect on January 1, 2012 with pilot implementation in Lagos State and later moved into full execution in that State on April 1, 2012. Thereafter, the policy was extended to five states (Kano, Ogun, Rivers, Anambra, and Abia) and Abuja on October 1, 2013 and to the entire country on July 1, 2014. The cardinal objectives of the policy are: (i) to drive development and modernization of Nigeria payment system in line with vision 2020 goal of Nigeria becoming one of the top twenty economies of the world by year 2020, (ii) to reduce the cost of banking services (including the cost of credit) and drive financial inclusion by providing more efficient transaction options and greater reach, (iii) to limit high cash usage outside the formal sector and thereby improve the effectiveness of monetary policy in managing inflation and encouraging economic growth, and(iv) to curb some of the negative consequences associated with high physical cash usage, including high cost of cash: robberies, corruption and leakages through money laundering, fraud and cash-related crimes (Central Bank of Nigeria, 2011; Odior and Banuso, 2012; Shonubi,2012).

However, the following are vital issues of the cashless policy. First, there is a threshold of daily cumulative cash of N500, 000 and N3 million on cash withdrawals and lodgments by individual and corporate bodies respectively free of processing fees. At the conception of the policy in 2011, these were pegged at N150, 000 and N1 million but were later reviewed. This limit applies to all account so far as it involves cash, irrespective of the channel used. Second, there are processing fees for withdrawals above the limit, and it is $3 \%$ for individual and $5 \%$ for corporate bodies. Lodgment above the limit attracts $2 \%$ and $3 \%$ processing fee for individual and corporate bodies respectively. These processing fees are subject to review every six months. Thirdly, these fees do not apply to accounts operated by Ministries, Departments and Agencies of the Federal and State Governments, solely meant for the purpose of revenue collections. Exemptions are also extended to Embassies, Diplomatic Missions and Multi-lateral and Aid Donor Agencies, as well as Micro Finance Banks and Primary Mortgage Institutions (CBN, 2012). Reducing the huge population of Nigerians who do not have access to financial services is one of the major targets of the $\mathrm{CBN}$.

It should be said that as at now there are already some forms of cashless transactions that are taking place in Nigeria. It is noted that as at today there are up to seven different electronic payment channels in Nigeria, Automated Teller Machines (ATM), points of sales terminals, mobile voice, web, inter-bank branch and kiosks. E-payment initiatives in Nigeria have been undertaken by indigenous firms and have been stimulated by improvement in technology and infrastructure (Babalola,2008). As noted above, the cashless economy does not imply an outright end to the circulation of cash (or money) in the economy but that of the operation of a banking system that keeps cash transactions to the barest minimum. The CBN had set daily limits of cumulative withdraws and lodgments of N150, 000 for individuals and 1,000,000 for corporate customers (now N500,000 and N3million respectively). The operation of the system does not mean the individual/corporations cannot hold cash in excess of N150,000/N1million (now N500,000/N3million respectively) respectively at any single point in time but that their cumulative cash transactions with the bank must not exceed these limits over a period of one day. The system is targeted at encouraging electronic means of making payments, and not aimed at discouraging cash holdings.

This policy on limits implies that an individual can actually have N5,000,000 (more than N150,000 now N500,000) under his pillow at home, buys goods and services with them but must not pay more than N500,000 into his bank in one day without attracting a fine of 5\% per 1000 for the excess. What is anticipated by this policy is that instead of making large withdrawals to effect payment for goods and services, such monies will be kept in the banking system so that payments are made through "credit card-like means." In this system users are issued with electronic cards which can be slotted into special electronic machines in order to effect payments. At the centre of such payment system are the Point of Sales (POS) terminals (Azeez, 2011). These are to be deployed across commercial points in the country. These POS terminals thus deployed will serve like the Automatic Teller Machines (ATM). In this case, upon completing a transaction and the value ascertained, the amount is entered into a POS terminal into which the electronic card has been slotted. The cash equivalent of the amount is transferred from the payer's account into the account of the payee automatically (Olaegbe, 2011). 
Users are issued with a card (the electronic purse). The electronic purse is topped up using revaluation terminals. There are different types of terminals: coin \& note, credit card and payroll deduction terminals. The cards are simply inserted into the revaluation terminal and certain programmed instructions are followed, and money is added onto the electronic purse. This can then be used to pay for goods/services by inserting them into the POS terminals. When the card is inserted into the POS, and the transaction amount entered, the reader reads the amount and is quickly deducted from the e-purse (the card).It has to be noted that the operation of the cashless economy (electronic payment) system is not entirely free. It is noted that curiously, using the POS comes with a hefty price tag of 1.25 percent of the cost of every purchase or transaction that is affected in addition to the 5 for every 1000 Commission on Turnover that our deposit money banks are allowed by CBN to charge every time money is taken from our account (Omose, 2011).

A survey on enhancing financial innovation and access in2010, revealed a marginal increase of those served by formal financial market from $35 \%$ in 2005 to $36.3 \%$ in 2010 ; five years after the launch of Micro finance policy which was thought could massively mobilize rural Nigerians into formal financial services (Onyinye, 2012). The survey attributed the reasons why most Nigerians do not have or maintain a bank account to unsteady income, unemployment and distance to bank branches. Accordingly, the CBN targeted to increase the number of Nigerians in the formal sector from its figure of 36.3\% in 2010 to above70\% by 2020 (The Nigerian Voice, 2013; The Nation, 2013). In pursuant of the foregoing, the CBN has undertaken a number of strategic initiatives, including a commitment at the 2011 Alliance for Financial Inclusion Global Forum held in Mexico to reduce Nigeria's financial exclusion from $46.3 \%$ to $20 \%$ by 2020 . One way to realizing this is to facilitate access to the otherwise disadvantaged groups like the farmers, aged citizens, self-employed, jobless school leavers and SMEs considered by banks a costly, risky and unviable bankable population (Onyinye, 2012). Also, the introduction of mobile money services by the CBN is seen as a veritable tool to create payment access to those unbanked Nigerians in the rural areas, and also help drive financial inclusion in the country. Financial analysts are of the view that the high level of mobile telecommunications usage in the country is expected to translate into increase in bankable Nigerians if perfectly harnessed (Amaka, 2012). Echekoba and Ezu (2012), in a research carried out in Nigeria, observed that $68.2 \%$ of the respondent complained about long queues in the bank, $28.9 \%$ complained of bad attitude of teller officers (cashiers) while $2.89 \%$ complained of long distance of bank locations to their home or work places. Likewise, in her 24th NCS national conference in December 2011, CBN data shows that $51 \%$ of withdrawal done in Nigeria was through automated teller machine (ATM), while 33.6\% was through over the counter (OTC) cash withdrawals and $13.6 \%$ through Cheques. Payment was also done through point of sales machine (POS) which accounted for $0.5 \%$ and web $1.3 \%$. Therefore, if the introduction of ATM in Nigeria cash withdrawals system reduced OTC withdrawal; then it implies that introduction of cashless policy supported by application of information technology can achieve more to reduce over dependent on cash payment in Nigeria economy system.

Electronic-based transaction seeks to drive the development and modernization of Nigeria's payment system in line with her goal of being among the top 20 economies of the world by the year 2020 (Central Bank of Nigeria, 2011). The essence of the policy is to shift the economy from a cash-based economy to a cashless one. Thus, it is geared towards engendering an efficient payment system anchored on electronic - based transactions. It is a truism that an efficient and modern payment system is a key enabler and a sine qua non for driving growth and development. The policy also aims at improving the effectiveness of monetary policy in managing inflation in the economy ( $\mathrm{CBN}, 2011)$. The cashless policy applies to all accounts, including collection accounts and the cash limits apply to an account irrespective of channel (i.e. whether it is over the counter, ATM, third party cheques cashed over the counter etc). As far as cash is involved, any withdrawal or deposit that exceeds the limits attracts a service charge (Central Bank of Nigeria, 2011). The charge is borne by the account holder and is about N100 per every 1000 in bank charges (This day Live 2012, April 25). The limit however does not prevent customers from withdrawing or depositing beyond the pegged limits but such customers should be prepared to pay the aforementioned penalty fee. One of the prerequisite for the development of national economy according to Ajayi and Ojo (2006) is to encourage a payment system that is secure, convenient, and affordable. In these countries, for instance, it is possible to pay for a vending machine snack by simply dialing a number on one's phone bill. In recent times, the mobile phone is increasingly used to purchase digital contents (e.g. ringtones, music or games, tickets, parking fees and transport fees) just by flashing the mobile phone in front of the scanner at either manned' or unmanned point of sales (POS).

Increasing numbers of countries have adopted policies to accelerate the use of electronic channels and reduce the use of cash. The motivation for these policies varies: many are primarily concerned with reducing tax evasion, some with fighting crime, and a few are now explicitly linked to financial inclusion-though the latter link is not necessarily immediately nor automatically achieved. 
Cashless Economic Policy in Nigeria: A Performance Appraisal of The Banking Industry.

\subsection{Theoretical Framework}

Although the concept of economic development was popularized in the $20^{\text {th }}$ century, the term actually predates this period to the era of the 'older historical school of economics' in the $19^{\text {th }}$ century. Economists of this era advocated a common historically based methodology to their economic analysis, as well as the belief that the chief task of economics was to discover the laws governing the stages of economic growth and development. For example, the German economist Georg Friedrich List (1789-1846), who is regarded as the forefather of the German historical school of economics, stated that economies of the temperate zone will go through four stages of economic development namely - pastoral life; agriculture; agriculture and manufacturing; and manufacturing, agriculture, and commerce.

Another German economist, Bruno Hildebrand (1812 - 1878), took a variant yet historical approach to the study of the stages of economic growth and development. He asserted that the key to understanding the stages of economic growth was to be found in the conditions of exchange; thus, he posited three economic stages based on barter, money, and credit. This assertion is known as the Theory of the Monetary Stages of Development and forms the subject matter of this paper. Hildebrand's theory of monetary stages of development explained that an economy would develop along three stages of the mediums of exchange namely - barter, money, and credit. Barter exchange, according to Hildebrand (1878) referred to the natural economy where goods were exchanged directly for other goods. The money exchange system meant that goods and services were exchanged in coinage, which was the principal form of money at the time, in the form of the two precious metals - gold and silver (hence, the gold and silver standards of the late $19^{\text {th }}$ and early $20^{\text {th }}$ centuries). The ultimate transition to the credit economy meant the use of paper money and paper transfers such that wage earners at the time could access credit for property purchases on account of promissory paper notes. As another economist aptly describes:

...Hildebrand's vision of society [was one of...] advancing from barter to monetary exchange before reaching its highest synthesis in a credit economy [where the] property-less wage earner [could have] access to capital and thereby resolve one of modern society's most pressing problems...

Although Hildebrand eventually failed to develop a coherent system of economics ${ }^{\mathrm{i}}$, his vision of a barter-money-credit advancement model of economic development provides theoretical evidence of the existing relationship (or correlation) between the mediums of exchange and economic development.

\subsection{Empirical Framework}

Looking at empirical issues, however, in a cashless economy, money demand equation can be derived without influencing output and inflation (Gali, 2008). In this case, money plays the role of a unit of account and the amount of real money balances follows residually after output, inflation and interest rate have been determined.

In examining the cost implications of cashless banking instruments, Gresvik and Owre (2002) studied how much it costs Norwegian banks to process various payment instruments. It finds that payment cards used for cash withdrawals at ATMs cost considerably more since the transactions involve cash replenishment, maintenance and security costs. In addition, the cost of using cheques for cash withdrawals was found to be three times more expensive than cash withdrawals at ATMs. Cross country studies such as Humphrey et al (1996) analyzed patterns in the use of cash and other e-payment instruments in 14 developed countries, including the US. Whilst treating payment instruments as if they were traditional goods, the authors construct measures of the cost (analogous to prices) of various payment methods in order to study whether differences in cashless instrument usage across countries can be explained by differences in the relative prices of such instruments. The result showed that such price differences failed to determine the usage of e-banking instruments. In other words, the convenience of using a particular instrument - a factor that is not measured may outweigh the price differences that users face (Carrow and Staten, 2000). Okoye and Ezejiofor (2013) examined the significant benefits and essential elements of cashless policy, and the extent to which it can enhance the growth of financial stability in the country. The descriptive research design was adopted for the study with a sample size of 68 questionnaires arrived at using the convenience sampling technique. The data collected was subjected to face validity test, and was tested with ANOVA and chi - square (x2) technique and the results indicate that: majority of Nigerians are already aware of the policy and majority agree that the policy will help fight against corruption/money laundering and reduce the risk of carrying cash. Major problems envisaged to hamper the implementation of the policy are cyber fraud and illiteracy. Based on the findings, they recommended that government should adopt a different strategy to educate the non-literate Nigerians about the cashless economy; and a framework should be worked out to provide cyber security in Nigeria.

Muhammad (2012) in an article titled analysis of value creation of electronic banking in Nigeriaexamined trends of banking habit in Nigeria across banking regimes of regulation and deregulation hinged on historical perspective of banking development in Nigeria, from independence to 2012. Relevant secondary data covering 1960 to 2010 were collected from Central Bank of Nigeria annual reports and analysed 
using the descriptive trend analysis. Muhammad (2012) finding suggests a static behavior across the monetary policy regimes and thus cautioned rushing the cashless program until measures are in place to encourage and push fast the banking culture change for the success of the cashless Nigeria program. In a like manner, Nwankwo and Eze (2013) ascertained the extent to which electronic payment affect cashless economy of Nigeria using a descriptive research design. Nwankwo and Eze (2013) indicates that the electronic system of payment has a great implication in cashless economy of Nigerian but that it will lead to significant decrease in deposit mobilization and credit extension by Nigerian deposit money banks. They concluded that cashless system of payment need to be examined and the e-payment system developed, so that people will get used to it before talking of cashless economy. This is because; bulk of the Nigerian economy is driven by SME and petty traders. To retain this policy of cashless economy in Nigeria, the authors recommended that the migration of our payments system towards a cashless society would require some reforms and a lot of effort and sensitization especially for low income group, who are currently deeply rooted in using cash and see it as a convenient and easy way of receiving and making payments.

Osazevbaru and Yomere (2015) explored the benefits and challenges of the cashless policy vis-à-vis the cash based policy. Specifically, Osazevbaru and Yomere (2015) seek whether other Point of Sales card acceptance services stakeholders attract a significant part of banks' income in cash-less economy. To address this, secondary data were collected and content analysis applied in data analysis. After factoring in other POS stakeholders share of income, the study found banks' income higher in cash-less setting than in cash based arrangement. Thus, the cash-less policy offers immense benefits to the banking sector (Osazevbaru and Yomere, 2015) concluded.

Banks have no doubt invested much on technology; and have widely adopted electronic and telecommunication networks for delivering a wide range of value added products and services. They have in the last few years transformed from manual to automated systems. Unlike before when ledge-cards were used, today banking has been connected to information technology networks, thereby facilitating the practice of interbanking and inter-branch banking transactions. Development domestically has the introduction of mobile telephone in 2001 and improved access to personal computers and internet service facilities have also added to the growth of electronic banking in the Nigeria banking sector. However, whereas local banks most commonly practice real time online internet banking, the integration of customers into the process is far from been realized.

\subsection{Electronic Banking Guidelines}

The electronic banking guidelines emerged from the findings of a Technical Committee on Electronic Banking set up by the Central Bank of Nigeria in 2003 to find appropriate modalities for the operation of electronic banking in the country. It was indeed the findings and recommendations of the committee that led to the adoption of a set of guidelines on Electronic Banking in August 2003. Of the key provisions of the guidelines, only a section deals with issues relating to Internet Banking Section 1.3 paragraph 4 of the guidelines, exceptionally stresses that banks should put in place procedures for maintaining the bank's Web site, including the various security features needed for Internet banking services (CBN, 2003).

Despite its numerous technical specifications, the guidelines have been widely criticized as not being enough to check the growing popularity of Electronic banking against the backdrop of growing sophistication in technology related crimes and frauds. Closer examination of the contents of the guidelines equally shows that the document fails to meet up with the four key areas where Electronic banking may have regulatory impact changing the traditional lines upon which existing regulatory structures are laid; handling concerns about existing public policy issues; changing the nature and scope of existing risks; and re-balancing regulatory rules and industry discretion. Again, some important recommendations of the Technical Committee that gave rise to the adoption of the guidelines were completely omitted. This is especially so with paragraph 6.1 of the Committee's report, which among others recommended that all banks, intending to offer transactional services on the Internet /other e-banking products, should obtain an approval-in-principle from CBN prior to commencing these services.

\subsection{Instruments/Channels of Cashless Policy}

Humphrey and Berger (1990) presented one of the earliest attempts to comprehensively estimate the private and social costs for nine separate payment instruments- cash, cheques, credit cards, money orders, point of sale (POS), Automated Clearing House Transfers (ACH), ATM bill payments, travelers' cheques and wire transfers. They found that from a social cost perspective, cash is the cheapest payment instrument, followed by $\mathrm{ACH}$, POS and ATM bill payment. From a private perspective, cheques emerge as the cheapest payment method followed by cash, ATM and POS bill payments. However, the influence of government intervention was prematurely considered as there was no calculation of net benefits of such payments instruments (Daniel et al, 2004). In recent times, there is a consensus that central banks have the capacity to control the price level. One of the approaches is through controlling money supply (advocated by monetarists) and has led many central banks 
to implement money-supply-targeting procedures (Claudia, 2001). Another approach is the Taylor-principle, which is, adjusting short-term interest rate in response to movements in expected inflation and state of economic activity, as shown in Taylor (1993), Clarida et al (1997) and Woodford (2003). At present, the situation does not seem to have shown any significant improvement. Whereas about 90 percent of the banks in the country offer other forms of electronic banking services like telephone banking. ATM and electronic fund transfer, Internet banking is yet to take centre stage. This aspect of banking is still at the basic informative stage (Ovia, 2001). This is so despite the widely acclaimed benefits of Internet banking against the traditional branch banking practice. Part of the reasons identified for the inability of banks in Nigeria to take full advantage of this mode of banking includes lack of adequate operational infrastructure like telecommunication and power, upon which Electronic banking generally relies. Due to the inability of the banks to integrate their operations into the Internet development process, Internet banking can be said to have less in the existing banking structure in the country. In addition, the fact that internet usage in the country has been abused by cyber criminals makes its window unattractive for domestic banking operations and legitimate international operations. The inherent fear associated with patronizing internet banking services in Nigeria is again re-enforced by the growing evidences that the world over, dubious Nigerians use fake websites to scoop funds from unsuspecting victims. In some cases, these crimes are committed using existing bank sites. The most common cash-less banking channels world over and through which the $\mathrm{CBN}$ policy is expected to yield result include:

$\square$ The Automated Teller Machine (ATM) and Cheque: Worldwide, the use of paper cash still remains the most widely used and acceptable means of settling financial transactions and obligations. However, the proportion of cash transactions is increasingly on the decline, especially in advanced economics (Amedu, 2005). In USA, where the use of cash is still prominent, compared with European countries, it represents 50 percent or more of the total transactions. Of course, cash is a non-electronic payment method. However, the physical carriage of cash as well as the visit to the bank branches is being reduced by the introduction of an electronic device. The Automated Teller Machine is a computerized device that provides the customers of a financial institution with access to financial transactions in a public place without a need for assistance from bank teller or any official. It is commonest form of electronic banking which has gain popularity among the people including unlettered customers.

A cheque is a paper based payment instrument whose usages are still gaining ascendancy. The Automation focus on this instrument is to reduce the number of clearing days and improve on security arrangement in the course of settlement and collection. For example, in Nigeria the Central Bank of Nigeria $(\mathrm{CBN})$ has just embarked upon online clearing and Nigeria has signified interest and signed path to this project (Johnson, 2005). Desirous of making the policy succeed, the apex bank has introduced a number of financial services which among others include mobile money payment system, point of sale terminals, Alerts and Automated Teller Machines (ATM). Essentially, Mobile Payment System introduced at the dawn of January 1, 2012 allows users to make payments with their GSM phones. It is a saving device and transfer system that turns GSM phone into a saving account platform, allowing owners to save money in it and also make transfers. The Point of Sale (POS) terminals are installed by businesses and connected to the Nigeria Inter Bank Settlement System for purposes of making payments during business transactions (Wikipedia, 2013).

$\square$ Mobile banking: This involves the use of mobile phone for settlement of financial transactions. This is more or less fund transfer process between customers with immediate availability of funds for the beneficiary. It uses card infrastructure for movement of payment instructions as well as secure SMS messaging for confirmation of receipts to the beneficiary. It is very popular and exciting to the customers given the low infrastructure requirement and a rapidly increasing mobile phone penetration in the country. Services covered by this product include account enquiry; funds transfer; recharge phones; changing password and bill payments. Even though the product is exciting most customers are yet to fully buy into it in Nigeria. Hence, both the apex bank and other banks still have a lot to do in term of increasing awareness of the product to the saving populace in the country.

$\square$ Internet banking: This involves conducting banking transactions on the internet (www) using electronic tools such as the computer without visiting the banking hall. E-commerce is greatly facilitated by internet banking and is mostly used to effect payment. Internet banking, like mobile banking, also uses the electronic card infrastructure for executing payment instructions and final settlement of goods and services over the internet between the merchants and the customers. Commonly used internet banking transactions in Nigeria are settlement of commercial bills and purchase of air tickets through the websites of the merchants. Level of awareness of the advantages of this product to the saving populace is still very low; hence there is every room for improvement if cashless banking would be effective as expected. 
$\square$ Telephone banking: Here the customer can assess their accounts using telephone lines as a link to the financial institution's computer centre. Services rendered here include account balance transfer; change of pin etc. This product has also experienced low patronage due to inadequate awareness and education of the customer on how to maximally use their phone to transact simple banking operations.

$\square$ The Card System or Electronic Card: The card system is a unique electronic payment type. The smart cards are plastic devices with embedded integrated circuit being used for settlement of financial obligations. The power of cards lies in their sophistication and acceptability to store and manipulate data, and handles multiple applications on one card securely (Amedu, 2005). This is a physical plastic card that uniquely identifies the holder used in transacting business on the internet, automated teller machine (ATM) and point of sales (POS) terminals. Carow and Staten (2000). This includes debit and credit cards, debit cards are linked to local bank accounts and offer immediate confirmation of payment while credit card can be used for assessing local and international networks.

As credit cards are widely accepted in most countries, the underlying infrastructures and operational rules are often provided by global trust scheme (such as visa and master card) in addition to local lines. Debit cards are the dominant cards in Nigeria, they are also known as ATM cards and their usage is wider than POS transactions given the current limited deployment of POS terminals. Depending on the sophistication, it can be used as a Credit Card, Debit Card and ATMs (Automatic Teller Machine). While the electronic card is gaining popularity in USA and Nigeria, the Spanish financial Institution demonstrated the highest implementation and update of smart cards across Europe (Amedu, 2005). The Smart Card was introduced into the Nigerian market to reduce or eliminate problems of carrying cash about (Amedu, 2005). It is electronically loaded with cash value and carried about like credit card and stores information on a microchip. The microchip contains a "purse" in which value is hold electronically. In addition, it also contains security programs; these protect transactions between one card user and the other. It can also be transferred directly to a retailer, merchant or other outlet to pay for goods and services, and like cash, transaction between individual without the needs for banks of the other third parties. Also, the system does not require central clearing. It is valued immediately. Also the system allows transfer of one value to the other hence it operates like cash.

$\square$ Point of Sale (POS)/Point of Purchase (POP) terminals: POS or POP is the location where a transaction occurs. A terminal or POS or POP is generally referred to the hardware and software used for check out, the equivalent of an electronic cash register. A POS manages the selling process by a salesperson accessible interface. The system allows the creation and printing of receipts.

\subsection{Benefits of the Cashless Policy to the Nigerian Economy}

Undoubtedly, an efficient payment system (which depends less on cash) is a sine-qua-non for national development and a significant national infrastructure for growth. All things being equal, it has been shown that $10 \%$ increase in the efficiency of the national payment system can cause the Gross Domestic Product to increase by $1 \%$ (Odior and Banuso, 2012). With the advent of cashless policy in Nigeria, what are the likely benefits? Opinions on this differ. On one side, we have those who are apprehensive about the policy. The assertion by Tunde (2012) sums up this: "Transaction charges are seen to make significant contribution to the profits of the banks. The cashless Nigeria programme has even brightened the horizon for the banks to make even higher income from transaction fees. Isn't this likely to result in "armchair banking" whereby banks will do little to mobilize deposits and build credit asset while also scaling back retail distribution outlet as has been reported? Are we likely to see some of the multiple fees consolidated to some point?"

On the other hand, there are those who are optimistic about the policy. For instance, Obina (2012) believes that if the reported two-third of the total cash in the economy which are outside the banking system is brought in (as it will be in cashless economy), the banks will have enough resources to do their businesses. Still expressing optimism, Obina (2012) agrees with the submissions of Laoye (2011), Akhalumeh and Ohiokha (2012), and Okey (2012) that if the cashless policy is successfully implemented, the following benefits will be attained:

i. A shift towards cashless policy will reduce the high operational cost incurred in a cash based economy. Such costs emanate from cash management and movement, currency sorting and printing.

ii. Cashless policy will enable Corporations benefit by way of faster access to capital, reduce revenue leakages and reduce cash handling cost.

iii. Cashless policy will help minimize the risks associated with the use of physical cash that do arise from burglaries and thefts as well as financial losses in fire outbreaks.

iv. Cashless economy will make every segment of the banking population to pay for it susage of cash. The situation in the cash based system where the majority small cash users pay for the minority high cash users 
will stop. There will be no more subsidies on cash transaction costs. To recapitulate, a survey conducted by the CBN in 2009 revealed that $90 \%$ of bank customers' daily withdrawals are amounts below N150, 000, whereas, only $10 \%$ of the bank customers who withdraw over N150, 000 are responsible for the rise in cost of cash management incurred by all the customers. Implicitly, the entire banking population supports financially the costs that the minority (10\%) incurs. A cashless economy will reduce this subsidy and makes the minority of the bank population account for the cost of cash movement they incur rather than the entire banking population.

v. Cashless economy will arrest a situation where a lot of cash are outside the formal banking system. By encouraging formal financial arrangement, it will facilitate the effectiveness of monetary policy in checking inflation and pushing economic growth.

vi. Furthermore, cashless economy is capable of reducing corrupt practices like money laundering which is common-place in cash based economy. To the extent that cash is not easily pulled out of the system, it will discourage launders.

vii. The cashless economy will bring about increased convenience, more service option, reduced risk of cash related crimes, cheaper access to banking services, and credit to customers. Retailers would benefit from a switch to electronic payments by not having to carry or handle large physical sums of currency, which would also reduce their costs and susceptibility to theft. Electronic payments are likely to prove attractive to consumers as well. In particular, there is the potential pecuniary advantage of earning interest on unspent electronic purchasing power.

viii. On the part of the government, it will bring about increased tax collection, greater financial inclusion, reduced revenue leakages and increase economic development. It also helps in the area of budgeting, planning, accountability and improved government services. All payments are made easier with mobile payment system. For instance, members of the society can pay their utility bills through their mobile phone.

ix. For the Banking industry, efficiency through electronic payment processing, reduced cost of operations and increased banking penetration. (Oyetade and Ofoelue, 2012).Electronic payments promise to be very cost efficient in comparison to prevailing paper-based payments systems. A switch from paper to electronic media is likely to cut deep inroads into bank costs, particularly labor costs, of routine processing of currency and paper-based payment instruments.

x. Through the system, users can pay utility bills, school fees, hotel bookings, and house rents, among other transactions, using a mobile phone device. (Eromosele and Obinna, 2012).

xi. Other stakeholders, the cashless system brings along with it different banking instrument such as POS systems, mobile payments, direct debits, internet banking, electronic fund transfer etc. Implicitly, companies that are connected with the production of these products will benefit. Such companies include: Nigeria Inter-Bank Settlement System Plc (a shared infrastructure company of the bankers committee with a mandate to continuously enhance the Nigeria payments system owned by all licensed deposit money banks in Nigeria and the CBN), POS manufacturers, telecom providers, and switch operators. In the case of smart cards with embedded value, the logistics of the issuer paying interest on the unspent balances are simple. As White (1995) has pointed out, this could be achieved by programming the card's microchip to augment the unspent card balance automatically over time. Where electronic payments are effected on-line to an interest-bearing bank account, the payment of interest would be obviously very straightforward.

Finally, according to Okogbue (2011) it is a well-known fact that the criminal underworld usually requires huge volumes of cash to carry out their despicable operations in order to avoid being traced or tracked. Therefore, placing a limit on the amount of cash flowing in the system, will curtail such activities as armed robbery, kidnapping, drug and gun running and money laundering. In an environment of extensive and predominant use of cheques and e-payments, criminal transactions can be easily traceable and tracked.

\subsection{Challenges of the Cashless Economy}

Notwithstanding the fact that the cashless policy comes with enormous benefits, there are also some envisaged challenges that could confront the policy. Akhalumeh and Ohioka (2011) observed some challenges with the introduction of cashless policy. Their findings show that $34.0 \%$ of the respondents cited problem of internet fraud, $15.5 \%$ cited problem of limited POS/ATM, $19.6 \%$ cited problem of illiteracy and $30.9 \%$ stayed neutral - the respondent not been sure of problem been expected or experienced. While in some quarters there was fear of unemployment, some believe it will create more jobs especially when companies manufacturing POS machine are cited in Nigeria.

More so, data sourced from Central Bank of Nigeria portal shows that Lagos state, with a population of 17 million people, only has sixty-one Point of Sales (POS), twenty bank branches and twenty four ATMs per 100,000 people which are far less to satisfy the needs of the population. These data verify the claim of Echekoba and Ezu (2012) on the problem of cash based economy and cashless policy in Nigeria. For effective cashless 
implementation in Nigeria availability of sufficient and well-functioning infrastructure (notably electricity), harmonization of fiscal and monetary policy, regular assessment of the performance of cashless banking channels, consideration of the present state and structure of the economy, redesign of monetary policy framework and greater efforts towards economic growth whilst managing inflation should be considered (Odior and Banuso, 2012). These challenges identified by this study, and elsewhere by Okechukwu (2011), Ejiofor and Rasaki (2012) include, but not limited to:

i. The policy is challenged by financial infrastructure deficit. The cashless payment channels that are currently available are not adequate to cope with the demand of the policy if it is to be implemented religiously. This inadequacy of infrastructural facilities could be experienced by high queues at ATM points. Even the POS can only be seen in big shops etc. This means that the policy will require further investment of funds by operators and regulators. Central Bank of Nigeria together with the operators and regulators must be ready to invest heavily to make these transitions possible; Technology is not cheap and ever changing at a very fast pace. Investments in billions of dollars made in infrastructure, training, marketing, security, maintaining IT networks and so on will be on a yearly basis for the years to come.

ii. Given that the system is driven largely by ICT, the policy is exposed to dangers of fraudulent practices as any security lapses can be exploited by the astute fraudster to perpetuate fraud. NIBSS disclosed that in 2014, Nigeria recorded 1461 cases of fraud compared to 822 cases in 2013. It explained that from the 1461 cases, the value of attempted fraud reported was N7,750,152,748 while actual loss was N6,215,987,323 in 2014 compared to N19,148,787,069 attempts and N485,194,350 actual loss reported in 2013.

iii. Electricity is a critical infrastructure for an efficient e-payment system. Sadly, Nigeria cannot boast of steady power supply across its urban and rural areas. This will without doubt affect the success of cashless policy if not addressed.

iv. The high charges and fees on some of the electronic channels are capable of generating resistance by the banking public. For example, the recent re-introduction of charges for ATM withdrawals didn't go down well with the users.

v. To operate successfully in cashless economy, some level of literacy is required in view of the technology involved. Therefore, Nigeria with high rate of illiteracy will certainly have some challenges. Illiterate population would prefer to keep their money in cash.

\section{Summary of Literature Review}

A review of the literature above gives meaning to the concept of the cashless economic policy which is rooted on the Monetary Stages of Development theory as propounded by Hildebrand in 1878. Theory of monetary stages of development explained that an economy would develop along three stages of the mediums of exchange namely - barter, money, and credit. The Nigerian economy having undergone the barter and money stages is now in the third and final stage of monetary development. The literature review to a large extent enumerates various benefits as well as challenges facing the successful implementation of the cashless policy in Nigeria. However, on empirical grounds, the review of related literature suggests that empirical studies are yet to abound on the adoption of cashless policy in Nigeria and its anticipated effect on bank performance. This is the gap this study intends to fill.

\section{Research Methodology}

This research will basically compare bank performance under the cash based period vis-a-vis the cashless period. It relied heavily on historic data, as data that was used in the analysis generated from published annual reports and accounts of the sampled banks between the period of 2009-2011(cash based period) and 2012-2014 (Cashless period). Therefore, this study employed the Ex Post Facto research design. This is because it involves events which have taken place. The importance of Ex-Post Facto research is that it is a realistic approach to solving business and social science problems which involves gathering records of past events (Agbadudu, 2002). The nature of data used is secondary and sourced from the annual reports of selected banks in Nigeria. To avoid encountering too many gaps in data input and given the length of time after the adoption of the cashless policy in Nigeria, the time frame for the study was truncated to a six (6) year period i.e. 2009 to 2014 divided into two periods 2009-2011 (before the cashless policy) and 2012-2014 (after the adoption of the cashless policy) for a balance t-test analysis.

\subsection{Techniques of Data Analysis}

The study adopted the return on asset (ROA) as the measure of bank performance. The ROA is a functional indicator of bank's profitability. It is a ratio calculated by dividing profit before tax by total assets. ROA shows the profit earned per dollar of assets which reflects bank's management ability to utilize the bank's financial and real investment resources to generate profits (Naceur and Goaied, 2001).

Thus ROA is calculated as Profit before Tax 
Total Asset.

\section{Model Specification}

The model for the study is structured in a way to enhance comparisons of the pre and post periods, and to bring out any significant difference existing between the pre and post operational variable of performance given the adoption of the cashless policy. This is in line with past empirical studies that have considered two samples before and after the implementation of a policy specifically the bank consolidation exercise (see Adegbaju\&Olokoye, 2008; and Ugwunta, Ani and Ugwunayi, 2012).

In testing our hypothesis, the study employed the parametric statistical pooled variance/paired sample t-test model. This statistical tool focuses on the significant difference of chosen operational variable between two sample means observed at two points in time. In this version, the two samples are combined (pooled) to get a pooled variance and base the standard error of the difference in means on that single estimate; the resulting $\mathrm{t}$ can be compared directly to critical values from the $t$ distribution table. The choice of this technique is that it suits the analysis since a significance test of two sampled means (before and after the adoption of the cashless policy) is being compared. It is also based on the conditions for using the t-test that:-

i. The population from which the sample is drawn is (approximately) normally distributed.

ii. The two population variances are identical, whatever value they happen to have in other words, there is homogeneity of variances.

iii. The sample size is small (that is $\mathrm{n}<30$ ).

iv. The population standard deviation $(\mathrm{S})$ is unknown.

The decision is informed by comparing the paired p-value (significance level) with the 0.05 level of significance. The decision rule is to accept Ho, if calculated p-value $>0.05$ and otherwise to reject Ho, if calculated p-value $<0.05$.

The t-test statistics process is specified thus;

$\mathrm{t}_{1}+\mathrm{n}_{2}-2=\mathrm{X}_{1}-\mathrm{X}_{2}$

$\mathrm{S}\left(\mathrm{X}_{1}-\mathrm{X}_{2}\right)$

Where;

$\overline{\mathrm{X}_{1}}=$ Sample mean value of the specified variable in the cash based period.

$\overline{\mathrm{X}}_{2}=$ Sample mean value of the specified variable in the cashless period.

$\mathrm{S}\left(\mathrm{X}_{1}-\mathrm{X}_{2}\right)=$ the standard deviation of the difference in the pooled variance and thus calculated as:

$S\left(X_{1}-X_{2}\right)=\sqrt{ } \quad S^{2} P$

$=\sqrt{ } S_{X 1}^{2}-S_{X 2}^{2}$

$=\sqrt{ } \quad\left(n_{1}-1\right) S^{2}+\left(n_{2}-2\right) S^{2}$

$\mathrm{n} 1+\mathrm{n} 2-2$

Where;

$\mathrm{S}\left(\mathrm{X}_{1}-\mathrm{X}_{2}\right)=$ Population standard deviation.

$\mathrm{S}_{\mathrm{X} 1}^{2}=$ Sample variance value of variable in the cash based period.

$\mathrm{S}_{\mathrm{X} 2}^{2}=$ Sample variance value of variable in the cashless period.

$\mathrm{S}^{2} \mathrm{P}=$ Pooled variance of the two samples $=\left(\mathrm{n}_{1}-1\right) \mathrm{S}^{2}+\left(\mathrm{n}_{2}-2\right) \mathrm{S}^{2} \ldots \ldots$ (5)

$\mathrm{n}_{1}+\mathrm{n}_{2}-2$

$\mathrm{n}_{1}=$ Sample size of the cash based period

$\mathrm{n}_{2}=$ Sample size of the cashless period.

$\mathrm{n}_{1}+\mathrm{n}_{2}-2=$ Degree of freedom.

However, in the actual analysis, the Statistical Package for Social Sciences (SPSS) was used at a $95 \%$ confidence interval for the difference in means and at four and/or three degrees of freedom (df). 


\section{Summary of Findings Conclusion and Recommendations}

This section of the paper rounds off the research report. In this section, the study summarizes the findings while aligning results with the objectives set out in section one and thereafter drew conclusions based on findings. The study rounded off with appropriate recommendations towards the enhancement of cashless policy vis-a-vis performance of banks.

The objective of this study is to ascertain if there is a significant difference in the performance of banks in Nigeria given the adoption of the cashless policy. The study used the return on asset as a performance measure and thus hypothesized that there is no significant difference in the performance of banks in Nigeria before and after the adoption of the cashless policy. The decision rule that guided the rejection or otherwise of the null hypothesis is to reject the null hypothesis if the significance (2-tailed) value of the resulting $t$ is $<0.05$ otherwise the null hypothesis is accepted. The paired sample t-test presented below aided the rejection and or acceptance of the study hypothesis.

Table 1. Paired Samples Test

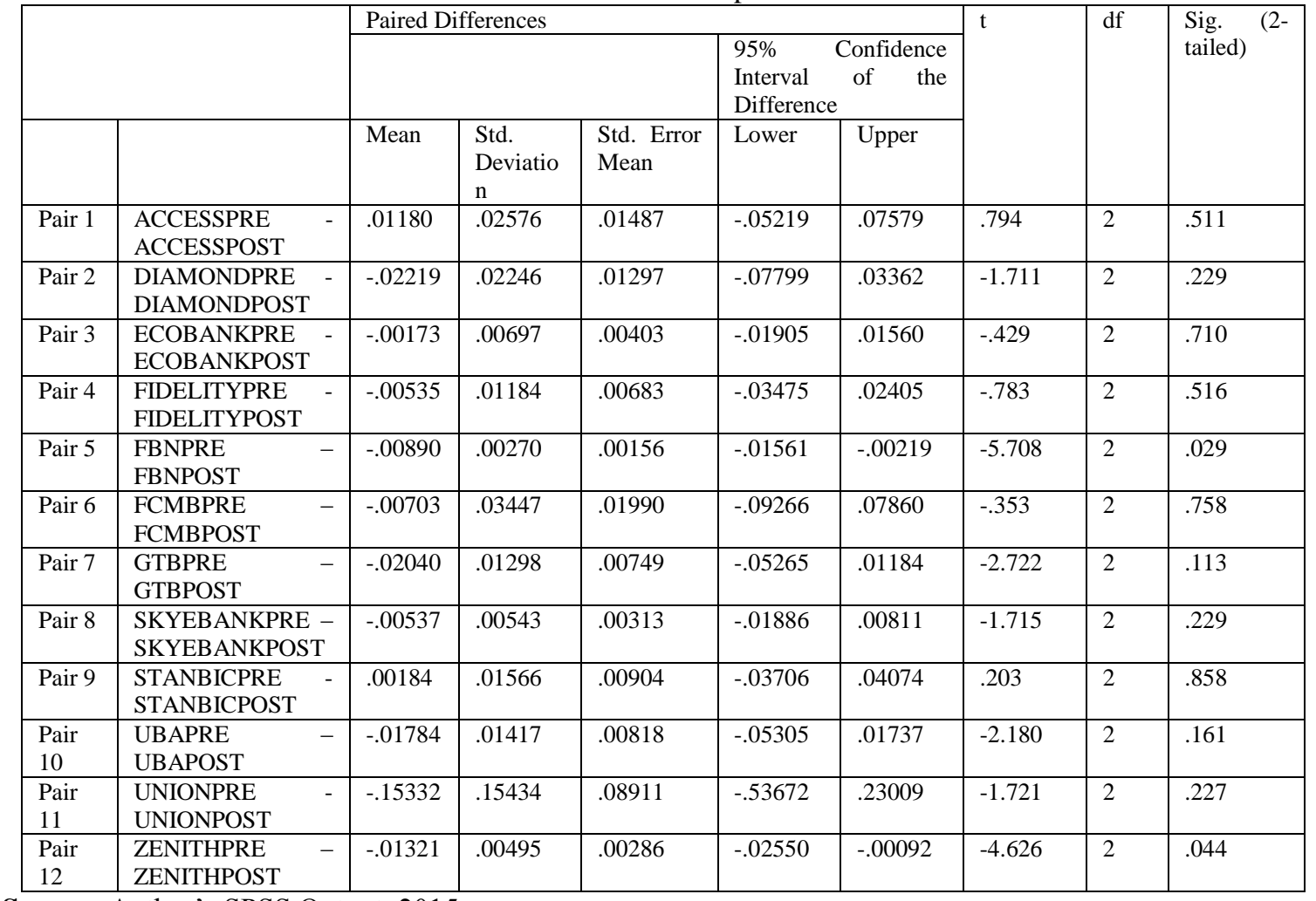

Source; Author's SPSS Output, 2015.

Table 1 above suggests that the significance (2-tailed) value of the resulting $t$ of .029 and .044 for First Bank of Nigeria Plc and Zenith Bank Nigeria Plc respectively <.05. Thus, we reject the null hypothesis that there is no significant difference in the profitability of Nigerian banks and thus conclude that there is a significant difference in the profitability of First Bank of Nigeria Plc and Zenith Bank Nigeria Plc.

\section{Summary of findings}

i. Income of banks in a cash-based economy is lower than the income of banks in cashless economy.

ii. The introduction of electronic banking in Nigeria has impacted positively on the development of the payment system in particular and the banking system in general given that the electronic banking is the platform on which the cashless policy sails. Other benefits include: the adoption of the policy has translated into improved services for customers; transaction charges are seen to make significant contribution to the profits of the banks; the cashlessprogrammein Nigeria has broadened the horizon for the banks to make even higher income from transaction fees; reduction in the high operational cost incurred in a cash based economy; mopping up currency outside the banking system thus enhancing financial intermediation; cashless economy will bring about increased convenience, more service option, reduced risk of cash related crimes, cheaper access to banking services, and credit to customers; for the banking industry specifically, efficiency through electronic payment processing, reduced cost of operations and increased banking penetration. All these benefits are expected to impact positively on the entire economy of Nigeria. 
iii. Challenges facing the policy include: problem of ICT related fraud; limited POS/ATM; high rate of illiteracy inhibiting usage of E-channel options; financial infrastructure deficit; and high charges and fees on some of the electronic channels. These are capable of generating resistance by the banking public.

\section{Conclusion}

In conclusion, findings from the study indicate that a shift towards cashless policy will reduce the high operational cost incurred in a cash based economy. Such costs emanate from cash management and movement, currency sorting and printing. Cashless policy will enable Corporations benefit by way of faster access to capital, reduce revenue leakages and reduce cash handling cost. Cashless policy will help minimize the risks associated with the use of physical cash that do arise from burglaries and thefts as well as financial losses in fire outbreaks. Cashless economy will make every segment of the banking population to pay for its usage of cash. The situation in the cash based system where the majority small cash users pay for the minority high cash users will stop. There will be no more subsidies on cash transaction costs.

\section{Recommendations}

Based on the findings from the study, the researcher recommends as follows:

a. Banks should invest more on ICT to enhance the efficiency of the e-payment systems. This will enhance bank income in the long-run.

b. To mitigate the challenges of the cashless policy it is recommended that financial infrastructures should be put in place to provide support for electronic banking equipment. Situations where banks have to provide own power supply practically every working day will increase overhead costs and diminish the gains accruable to them.

c. Further legal and regulatory framework that will check electronic fraud should be put in place by the government. The mandate of anti-graft agencies like the Economic and Financial Crimes Commission (EFCC) should be expanded to cover fraudulent practices that are associated with operations of cashless economy.

d. Finally, banks as well as CBN should embark on public enlightenment to educate the populace on the nittygritty of the cashless system. This will raise the level of awareness and reduce possible resistance by the banking public.

[1]. Adegbaju, A. A. and Olukoye, F.O. (2008). "Recapitalization and banks performance: A case study of Nigerian Banks", African Economic and Business Review, Vol. 6(1): 27-41

[2]. Adeyemi,K. S.(2006), "Banking Sector Consolidation: Issues and Challenges", A paper presented by an Executive Director, Union Bank of Nigeria PLC.

[3]. Agu, J.C. (2012), "Socio-Political Factors Affecting Project Planning, Management through Implementation in Nigeria", International Journal of Current Research, Vol. 4(11), 362-372.

[4]. Ajayi, M. (2006). "Banking sector reforms and banking consolidation: conceptual framework", Bullion, Vol. 29(2): 60-74

[5]. Akhalumeh. P. B. and Ohiokha, F. (2012). "Nigeria's cashless economy: the Imperatives", International Journal of Management and Business Studies, Vol. 2(2): 31-36

[6]. Amaka, E. (2012). "Prospects and challenges of mobile money in Nigeria economy", retrieved from http://www.thisdaylive.com/articles/prospects-and-challenges-of-mobile-money-onnigeria-economy/129273

[7]. Ashike, H. (2011), "Cashless Economy can Reduce Risk of Carrying Huge Cash",[Online]Available :http://www.businessdayonline.com/.../22217

[8]. Babalola, R. (2008). "E-payment: towards a cashless economy". Address by Minister of State for Finance at CardExpo Africa Conference. Retrieved from http://www.nigeriavillagesquare.com

[9]. Bank for International Settlements, (1996), - Implications for Central Banks of the Development of Electronic Moneyll, Basel

[10]. Basel Committee, (1998), —Risk Management for Electronic Banking and Electronic Money Activitiesll, Basel Committee Publications, No. 35

[11]. Central Bank of Nigeria, (2012). "Toward a cashless Nigeria: Tool and strategies", retrieved from www.ncs.org.ng/wpcontent/uploads/2012/08/cashless2012-4.pdf

[12]. Central Bank of Nigeria, (2011). "Guidelines on Point of Sales (POS) Card Acceptance Services", retrieved from www.cenbank.org

[13]. Central Bank of Nigeria, (2011). "New cash policy", retrieved from www.cenbank.org

[14]. Daniel, D. G., R. W. Swartz, and A. L. Fermar, (2004): - Economics of a Cashless Society: An Analysis of Costs and Benefits of Payment Instrumentsll, AEI-Brookings Joint Center

[15]. Ejiofor, V. E. and Rasaki, J. O. (2012). "Realizing the benefits and challenges of cashless economy in Nigeria: it perspective", International Journal of Advances in Computer Science and Technology, Vol. 1(1): 7-13

[16]. Hildebrand, B. (1986). International Encyclopaedia of the Social Sciences. Retrieved from http://www.encyclopedia.com/doc/1G23045000513.html

[17]. Humphrey, D. B. (2004), "Replacement of cash by cards in U.S. Consumer Payments", Journal of Economics and Business. 56, $211-225$.

[18]. Humphrey, D. B. and Berger, A. N. (1990), Market Failure and Resource Use: Economic Incentives to Use Different Payment Instruments, New York, Monograph Series in Finance and Economics.

[19]. Laoye, J. (2011). "Benefits of cashless economy by experts" retrieved from http://www.zumalist.com

[20]. Naceur, S. B. and Goaied, M. (2001). The determinants of commercial bank interest margin and profitability: evidence from Tunisia. Working paper 856365. htpp://www.papers.ssrn.com/sol3/papers.cfm 
[21]. Nweke, F. (2012)."Nigeria in 2012: The vision of cashless economy", The Nigeria

Economic Summit Group, Abuja. Retrieved from http://gadzama.com/publications/NIGERIA_2012 Vision_of a Cashless_Economy.d

[22]. Obina, C. (2012). "Going cash-less'll reduce cost of banking operations", This Day, retrieved from www.thisdaylive.com/articles/going-cash-less-11-reduce-cost-0of-banking-opera tions- /113437

[23]. Odior, S. E. and Banuso, B. F. (2012). "Cashless banking in Nigeria: challenges, benefits and policy implication", European Scientific Journal, Vol.8 (12), retrieved from eujournal.org/index.php/esj/article/view/192

[24]. Okechukwu, N. (2011). "Current Challenges will not stop cashless economy implementation",retrieved from http://www.archive.punchontheweb.com

[25]. Okey, O. O. (2012). "The Central Bank of Nigeria's cashless policy in Nigeria: Benefits andchallenges", Journal of Economics and Sustainable Development, Vol.3(14):128-133.

[26]. Okoye, P. V. C. and Ezejiofor, R. (2013), "An Appraisal of Cashless Economy Policy in Development of Nigerian Economy", Research Journal of Finance and Accounting, Vol.4, No.7, 2-15, Retrieved from http:// www.iiste.org

[27]. Onyinye, N. (2012). "Banking the unbanked still the CBN's major hurdle", Microfinance Nigeria, retrieved from http://www.microfinancenigeria.com/latest-news/

[28]. Osazevbaru, H. O. and Yomere, G. O. (2015), "Benefits and Challenges of Nigeria’s Cashless Policy",Kuwait Chapter of Arabian Journal of Business and Management Review, Vol. 4, No.9; 1-8

[29]. Princewell, N. A. and Anuforo, R. (2013). "Shifting policy paradigm from cash-based to cashless economy: the Nigeria experience", retrieved from http://www.onlineresearch journals.com/aajoss/art/124.pdf

[30]. Roth B.L. (2010), "The Future of Money: The Cashless Economy - Part 1",[Online]Available:http://www.x.com/.../future_money_cashless_economy_part_1.

[31]. Shonubi, A. (2012). "Towards a Cashless Nigeria: Tool and Strategies; Business Implications", A presentation at the Nigeria Computer Society 24th National Conference, Abuja, July 25.

[32]. The Nation, (2013). "30.7m Nigerians have bank accounts, says CBN", retrieved from http://thenationonline.net/news/13231/1cbnissues-new-guidelines-for-financial-inclusionstrategy-.html

[33]. The Nigerian Voice, (2013). "CBN issues new guidelines for financial inclusion strategy", retrieved from http://www.thenigerianvoice.com/news/13231/1 cbn-issues-new-guidelines-forfinancial-inclusion-strategy-.html.

[34]. Tunde, L. (2012). "Cashless policy will lower cost of accessing finance", retrieved fromhttp://www.Nigeriadevelopmentandfinanceforum.org/PolicyDialogue/Dialogue.aspx

[35]. Ugwunta, D.O., Ani, W.U., \&Ugwuanyi, G. (2012). The effect of bank consolidation on bank credit reduction: evidence from selected banks $\quad$ in Nigeria. International Journal of Business and Management $\quad$ Tomorrow Vol. 2(3), 1-8

[36]. Woodford, M.(2003), "Interest and Price : Foundation of a Theory of Monetary Policy", 7. Princeton University Press,

[37]. World Bank Approves Cashless Policy", (2011), [Online] Available: http://www.coly flavourmegzine.com/?

Appendix.

\begin{tabular}{|c|c|c|c|}
\hline & & ACCESS & \\
\hline Years & PBT & TA & ROA \\
\hline 2014 & $46,142,422$ & $1,981,955,730$ & 0.023281 \\
\hline 2013 & $31,365,396$ & $1,704,094,012$ & 0.018406 \\
\hline 2012 & $37,028,147$ & $1,515,754,463$ & 0.024429 \\
\hline 2011 & $12,141,462$ & $949,382,097$ & 0.012789 \\
\hline 2010 & $17,668,584$ & $726,960,580$ & 0.024305 \\
\hline \multirow[t]{2}{*}{2009} & $41,723,000$ & $647,574,719$ & 0.06443 \\
\hline & & Diamond & \#REF! \\
\hline 2014 & $24,413,014$ & $1,750,270,423$ & 0.013948 \\
\hline 2013 & $33,250,472$ & $1,354,930,871$ & 0.02454 \\
\hline 2012 & $28,364,965$ & $1,178,103,754$ & 0.024077 \\
\hline 2011 & $-27,132,209$ & $796,231,792$ & -0.03408 \\
\hline 2010 & $9,468,016$ & $548,402,560$ & 0.017265 \\
\hline \multirow[t]{2}{*}{2009} & $8,343,738$ & $650,891,836$ & 0.012819 \\
\hline & & ECOBANK & \#REF! \\
\hline 2014 & 519,549 & $24,243,562$ & 0.02143 \\
\hline 2013 & 221,778 & $22,532,453$ & 0.009843 \\
\hline 2012 & 348,024 & $19,950,335$ & 0.017445 \\
\hline 2011 & 277,422 & $17,161,912$ & 0.016165 \\
\hline 2010 & 169,026 & $10,466,871$ & 0.016149 \\
\hline \multirow[t]{2}{*}{2009} & 101,066 & $9,006,523$ & 0.011221 \\
\hline & & Fidelity & \#REF! \\
\hline 2014 & 15,515 & $1,187,025$ & 0.01307 \\
\hline 2013 & 9,028 & $1,081,217$ & 0.00835 \\
\hline 2012 & 36,637 & $1,333,031$ & 0.027484 \\
\hline 2011 & 14,274 & $1,029,926$ & 0.013859 \\
\hline 2010 & $6,831,645$ & $650,318,227$ & 0.010505 \\
\hline \multirow[t]{2}{*}{2009} & $3,074,418$ & $362,098,549$ & 0.008491 \\
\hline & & FBN & \\
\hline 2014 & 92,884 & $4,342,666$ & 0.021389 \\
\hline 2013 & 91,337 & $3,869,001$ & 0.023607 \\
\hline 2012 & $26,134,556$ & $2,047,496,098$ & 0.012764 \\
\hline 2011 & $17,637,486$ & $1,841,737,651$ & 0.009577 \\
\hline 2010 & 33,537 & $1,957,258$ & 0.017135 \\
\hline \multirow[t]{2}{*}{2009} & 7,689 & $1,772,456$ & 0.004338 \\
\hline & & FCMB & \\
\hline 2014 & $23,942,893$ & $1,169,364,784$ & 0.020475 \\
\hline
\end{tabular}


Cashless Economic Policy in Nigeria: A Performance Appraisal of The Banking Industry.

\begin{tabular}{|c|c|c|c|}
\hline 2013 & $18,184,399$ & $1,008,280,170$ & 0.018035 \\
\hline 2012 & $12,417,616$ & $890,313,606$ & 0.013947 \\
\hline 2011 & $-13,372,615$ & $593,114,362$ & -0.02255 \\
\hline 2010 & $7,564,888$ & $530,073,888$ & 0.014271 \\
\hline 2009 & $18,437,711$ & $465,210,901$ & 0.039633 \\
\hline 2008 & $7,390,228$ & $262,805,890$ & 0.02812 \\
\hline \multirow[t]{2}{*}{2007} & $3,640,697$ & $106,673,991$ & 0.034129 \\
\hline & & GTB & \\
\hline 2014 & $116,385,843$ & $2,126,608,312$ & 0.054728 \\
\hline 2013 & $107,091,256$ & $1,904,365,795$ & 0.056235 \\
\hline 2012 & $100,141,667$ & $1,620,317,223$ & 0.061804 \\
\hline 2011 & $64,745,101$ & $1,523,527,545$ & 0.042497 \\
\hline 2010 & $45,475,040$ & $1,066,762,763$ & 0.042629 \\
\hline \multirow[t]{2}{*}{2009} & $26,959,809$ & $1,019,911,536$ & 0.026433 \\
\hline & & SKYE & \\
\hline 2014 & 9,265 & $1,209,633$ & 0.007659 \\
\hline 2013 & 19,569 & $1,114,040$ & 0.017566 \\
\hline 2012 & 15,775 & $1,071,311$ & 0.014725 \\
\hline 2011 & 2,977 & 876,527 & 0.003396 \\
\hline 2010 & 11,445 & 674,064 & 0.016979 \\
\hline \multirow[t]{2}{*}{2009} & 2,148 & 622,164 & 0.003452 \\
\hline & & STANBIC & \\
\hline 2014 & 32,065 & 944,542 & 0.033948 \\
\hline 2013 & 20,773 & 763,046 & 0.027224 \\
\hline 2012 & 11,412 & 676,819 & 0.016861 \\
\hline 2011 & 9,976 & 554,507 & 0.017991 \\
\hline 2010 & 13,528 & 384,541 & 0.03518 \\
\hline \multirow[t]{2}{*}{2009} & 10,342 & 340,490 & 0.030374 \\
\hline & & UBA & \\
\hline 2014 & 42,378 & $2,338,858$ & 0.018119 \\
\hline 2013 & 51,841 & $2,217,417$ & 0.023379 \\
\hline 2012 & 46,180 & $1,927,257$ & 0.023962 \\
\hline 2011 & $-26,468$ & $1,666,053$ & -0.01589 \\
\hline 2010 & 16,359 & $1,432,632$ & 0.011419 \\
\hline \multirow[t]{2}{*}{2009} & 22,989 & $1,400,879$ & 0.01641 \\
\hline & & UNION & \\
\hline 2014 & 1,483 & 431,568 & 0.003436 \\
\hline 2013 & -571 & 489,215 & -0.00117 \\
\hline 2012 & 8,119 & 886,468 & 0.009159 \\
\hline 2011 & $-102,633$ & 827,153 & -0.12408 \\
\hline 2010 & $-12,398$ & 845,231 & -0.01467 \\
\hline \multirow[t]{2}{*}{2009} & $-285,370$ & 921,230 & -0.30977 \\
\hline & & Zenith & \\
\hline 2014 & 107,849 & $3,423,819$ & 0.0315 \\
\hline 2013 & 94,108 & $2,878,693$ & 0.032691 \\
\hline 2012 & 95,803 & $2,436,886$ & 0.039314 \\
\hline 2011 & 41,301 & $2,169,073$ & 0.019041 \\
\hline 2010 & 42,957 & $1,789,458$ & 0.024006 \\
\hline 2009 & 32,753 & $1,573,196$ & 0.020819 \\
\hline
\end{tabular}

Source: Annual Reports of Sampled Banks, 2009 - 2014. 